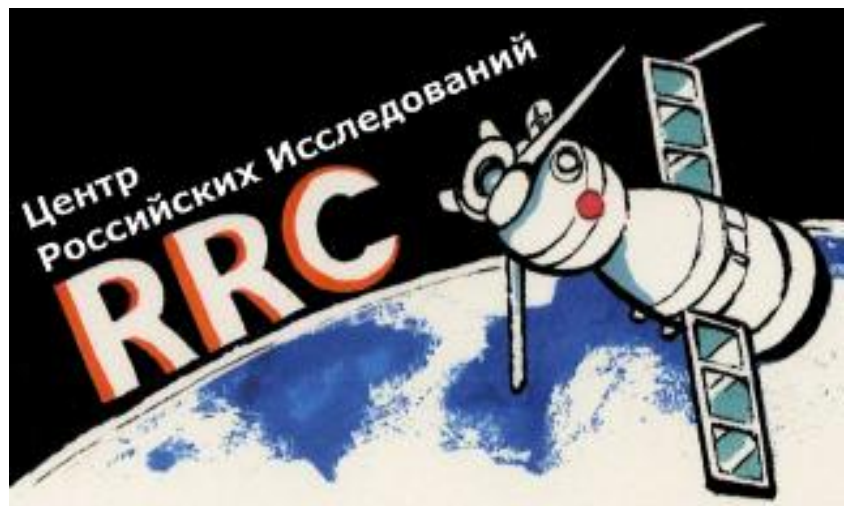

RRC Working Paper Special Issue No. 2

What did the study of transition economies contribute to mainstream economics?

Michael Ellman

June 2012

RUSSIAN RESEARCH CENTER

Institute of Economic Research

Hitotsubashi University

Kunitachi Tokyo JAPAN 


\title{
What Did the Study of Transition Economies Contribute to Mainstream Economics?
}

\author{
Michael Ellman \\ Amsterdam University Business School, Netherlands*
}

\begin{abstract}
The transition from state socialism to capitalism or market socialism has been a profound, indeed revolutionary, change in the socio-economic system of countries with about a quarter of the world's population. The IFIs (International Financial Institutions) have been closely involved in it for more than 20 years. It has also given rise to an extensive academic literature. The purpose of this paper is to argue that this experience, and the policy-related and academic discussion about it, has made a useful contribution to mainstream economics. This contribution is analyzed in the following sections.
\end{abstract}

\section{The need for an effective and accountable state}

Given the overwhelming role of the state in state socialism, it is understandable that the initial attitude of the reformers to the state was negative. They sought to weaken its influence on the economy and society, so as to let the free market develop. This was

\footnotetext{
* Publication of this paper is financially supported by a grant-in-aid for scientific research (A) from the Ministry of Education, Culture, Sports, Science and Technology of Japan (No. 23243032). I am grateful to P. Ellman, M. Harrison, S. Hedlund, P. Nolan, and V. Kontorovich for helpful comments and suggestions. The author alone is responsible for the interpretation and remaining errors.
} 
not just a reaction to the failure of the old system but was also partly based on the ideology of neoliberalism. Some of the reformers and their foreign advisers seem initially to have thought that it was only necessary to destroy the oppressive state and a healthy free market would spring up on its own as a result of Adam Smith's natural propensity for people to truck and trade. As Sachs (1993, p. xiii) put it, “...markets

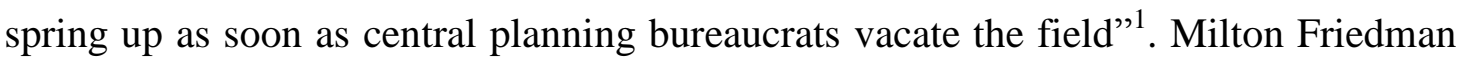
had earlier propagated the notion that "the state is not the solution but the problem". The 'new political economy'/public choice theory had stressed that bureaucrats are often more concerned with promoting their own interests than those of society as a whole. It also analyzed the inefficiency of regulatory agencies which are often captured by those they are supposed to be regulating. Unfortunately the transition began many years before the world economic crisis which began in 2008 exposed, for all to see, the limitations of neoliberalism and the economic system it justified.

Experience of the transition showed that the negative attitude to the state of the neoliberals (and the weakness of the state resulting from the end of the old system and the end of some former countries such as the USSR, the existence in some countries of a very polarized political system ${ }^{2}$, and the initial lack of functioning and effective new institutions) could have unfortunate results. Research on the Hungarian banking system led Abel and Bonin (1993) to point out the dangers of state desertion, that is

\footnotetext{
${ }^{1}$ This was partially correct, as the rapid growth of the de novo sector in the early stage of transition in Central Europe showed.

${ }^{2}$ For an interesting analysis of the political economy of transition which focuses on the effects of political polarization, see Frye (2010). In Frye's argument a major role is played by the taxes levied on the new private sector (these provide politicians with the incentive to pursue reforms). However, in some countries natural resource rents are key sources of state revenue and privatization may make it more difficult for the state to collect them. Moreover, taxing the new private sector, with its large number of small enterprises, is often more difficult than taxing the old state sector. The drive to transform society was driven by more than a wish to collect and distribute taxes from the new market sector. However, it is certainly true that a successful private sector will generate employment and indirect tax revenues (if there is an efficient tax system).
} 
the abandonment by the state of functions that are essential for the smooth running of a market economy. In Russia the abolition of the state monopoly of vodka in 19911992 without an efficient system for collecting excise taxes and customs duties led to a dramatic loss of revenue by the state budget, which contributed to the chronic fiscal problems and resulting inflation of the Yeltsin era (Eatwell et al., 1995, pp. 30-31). The notorious failure of the Russian state to control corruption, criminality and inequality was a major contribution to the poor economic performance in the first decade of transition and dissatisfaction and unrest in that country at the beginning of the third post-Soviet decade (Popov, 2012; Putin, 2012).

In view of these negative lessons, and the contrasting experiences of Russia and China (Nolan, 1995), the international community gradually came to realize the importance of an effective state for both guiding the transition process and forming part of its desired destination. In 1997 the World Bank devoted its World Development Report to 'The state in a changing world'. This argued (page 1) that "An effective state is vital for the provision of the goods and services - and the rules and institutions that allow markets to flourish and people to lead healthier, happier lives. Without it sustainable development, both economic and social, is impossible." This was not a new thought. The need of a strong state for a well-functioning market economy had been pointed out earlier by academics (e.g. Crouch, 1986), was an integral part of social-democracy, and was widely accepted in Asia. However, in the Anglo-Saxon countries it was shunted aside in the heyday of neoliberalism. It took the experience of transition for the World Bank to endorse it. In the last few years it has also been accepted by mainstream economics. Besley and Persson (2009, p. 1239) writing in the American Economic Review pointed out that the "creation of state capacity to collect taxes and enforce contracts is a key aspect of development" and that "state capacity cannot be taken for granted".

Creating an effective state, one which can analyse problems, reach sound conclusions, and then implement them, is a complex and difficult process. It requires 
an efficient bureaucracy, which is well paid and competent ${ }^{3}$. It also helps to have a legal system that provides redress against bureaucratic excesses and enables natural and legal persons to settle their differences ${ }^{4}$. In Russia a feature of the Putin era was the effort to strengthen the 'power vertical', i.e. to ensure that government decisions are actually implemented. Despite a decade of effort aimed at this, progress has been imperfect, with many decisions of the President and Prime Minister being ignored by lower level officials (Monaghan, 2012).

The transition also emphasized that what was required was not just a state that played an important role in the economy but one that acted in the interests of society as a whole - or at any rate a large part of it. A major danger in some of the transition countries, in particular in the FSU (Former Soviet Union), was state capture by elites which used it in their own pecuniary interests. Russia experienced, first, state capture by business interests, followed by business capture by the state (Yakovlev, 2006), neither of which were conducive to the development of a modern market economy the ostensible goal of the transition process. Bulgaria too is a case of very persistent state capture (Rusinova, 2010, pp. 46-48).

\footnotetext{
${ }^{3}$ In 2004 the pay of Russian officials was increased. This was intended to increase their willingness to carry out instructions, and reduce the time and energy they devote to their private money-earning activities. However, it failed to raise their pay to competitive levels (particularly in Moscow where a high proportion of them work), and failed to utilize effectively honors/awards (from which $90 \%$ of officials are excluded) and therefore (Kuz'minov et al., 2005, p. 61): "Qualitative changes in the loyalty of officials to the state did not take place". Oleinik (2011, pp. 319-321) pointed out that the administrative reforms in Russia in 2001-2005 were effective in raising the authority of the state but ineffective in raising its efficiency, as measured by the corruption indices of Transparency International or the Governance Indicators of the World Bank.

${ }^{4}$ As Kuz'minov et al. (2005, p. 41) observed, "the fate of judicial reforms in the Russian Federation has to be recognized as one of the saddest of our reforms. Since the beginning of reform in 199114 years have already passed but we do not yet have an independent judiciary which has the confidence of business and the population".
} 
The then Russian Prime Minister Putin (2012) publicly recognized the need for transparency and accountability of government organizations, but at the same time has prevented these things actually happening by electoral fraud, which deprives the public of influence over the state. It leaves the state under the control of irresponsible officials who pay little attention to costs or efficiency, but much attention to their own incomes and perks ${ }^{5}$. Oleinik (2011) has argued that in Russia a very specific economic system has emerged, one in which markets exist but the state controls access to the market (by its control over information flows, the legal system, particular regions, and particular markets) and uses it to generate administrative (i.e. bureaucratic/political) rent. As a result, prices are higher than they would otherwise be, market competition is limited, innovation is delayed, FDI (Foreign Direct Investment) is hindered, but officials enjoy their power and income. Not all the administrative rent is used for additional income of officials and foreign investment. Some is used for investment projects or popular social expenditures (e.g. housing, facilities for children or the elderly). This use of administrative rent enables politicians to increase their popularity, adding an element of populism. This system could be termed 'Capitalism with Russian characteristics'. It is a compromise between the Russian tradition of a state with extensive powers and citizens with few rights to curb the exercise of arbitrary state power, the elite's wish to enjoy the consumption benefits and technical progress of a market economy, and regular elections.

An interesting example of the possible gains from political accountability and transparency has been given by Ferraz and Finan (2011). They found that mayors in Brazil who cannot be reelected because of limits on their tenure are significantly more corrupt than mayors facing reelection and the difference decreases with the information available to voters (and the likelihood of prosecution).

\footnotetext{
${ }^{5}$ Opinion polls in Russia among both municipal and regional officials (in 2005), and the general public (in 2007) showed that in both groups the dominant opinion was that officials were mainly interested in ensuring their own income, wealth and influence and that the interests of the state and of the population as a whole were subordinate to this (Oleinik, 2011, p. 105).
} 
The need for an effective and accountable state is not something that was new and entirely unknown prior to transition. It is just that the experience of transition has emphasized it.

\section{The importance of institutions}

A striking result of the transition experience is that analysis of it led to a greater recognition of institutions in determining the course of economic development. The initial holy trinity of transition - stabilization, liberalization, privatization - rested on macroeconomics (stabilization); microeconomics (liberalization); property rights economics, 'new political economy'/public choice theory and Thatcherism (privatization), and experience in Latin America. The transformational recession (Kornai, 1994), and in particular its depth and length in the FSU, gave rise to the idea that something had been missing from the first prescriptions ${ }^{6}$.

After considering the various explanations that had been offered for the depth of the transformational recession, Schmieding (1993) concluded that it had not been caused by neoclassical or Keynesian factors but by institutional ones. It had not been caused by the endowment of factors of production (which had not changed), nor by insufficient mobility of factors, nor by factor price rigidity. The formal apparatus which concentrated on these issues, and took the institutional framework of the economy as given, was not relevant to what had happened (and what was still happening). Nor had it been caused by Keynesian factors. Neither inadequate aggregate demand nor a liquidity crunch were adequate to explain the depth and length of the transformational recession. Instead, Schmieding argued, building on the New Institutional Economics developed by North (1990; 1993), that the transition was

\footnotetext{
${ }^{6}$ However, it is worth noting that J. Williamson (1992, p. 12), the author who explicitly formulated the subsequently much-criticized Washington Consensus, quickly noted the importance of institutional change in the transition and its implications for economics. "If the subject of economics gains a new dimension out of the events in Eastern Europe, it will surely be by a new understanding of the institutional bases of a market economy".
} 
essentially an institutional revolution. During it the institutions relevant for one economic system decayed or were destroyed and new institutions were created. If the former proceeded faster than the latter, then an institutional void emerged with negative consequences for economic activity. Similar ideas were expressed subsequently by other authors such as Intriligator (1996), who concentrated on the Russian case. The introduction of institutional factors to explain economic growth was a radical innovation in mainstream growth theory, which had traditionally concentrated on the availability of factors of production, the efficiency with which they were used, and technical progress.

Following Schmieding, various authors set out to test this hypothesis. An early paper was Brunetti, Kisunko, and Weder (1997). This considered 20 transition countries in 1993-1995. They found for these years a positive relationship between credibility and growth and especially FDI. They concluded that "the results of this analysis suggest that the guarantee of a reliable institutional framework may be an important precondition for the successful transition and improved economic performance of former planned economies". A subsequent paper was Grogan and Moers (2001). This analysed 25 transition countries for the years 1990-1998. They found that (ibid., p. 341) "the quality of (particularly formal) institutions is significant for growth and FDI, the latter itself being important for the former. The correlation between the quality of institutions and growth is more likely to be a causation". They also found that the quality of institutions was a more important explanatory variable for growth and investment than a large number of other variables that are traditionally considered to determine them.

These findings rapidly became the new orthodoxy. This can be seen from the World Development Report 2002 of the World Bank which was entitled Building Institutions for Markets. However, the subsequent stress by the World Bank on the need for all countries to adopt liberal market institutions of the US type gave rise to considerable controversy (Chang, 2011). Ito (2009) suggested that the World Bank's understanding of economic growth, and its policy prescriptions, gave too little 
attention to the experience and performance of Asia. Xu (2011) pointed out that China fares badly on institutional development according to the standards of the Washington Consensus or recent econometric cross-country studies. The state is not separate from business, the rule of law and formal protection for private property are weak, and corruption is very widespread. Nevertheless, its growth is phenomenal. Xu suggests that the explanation is one very effective institution which it does have: regional decentralization within an authoritarian and centralized political system. This shows the importance of exploiting indigenous institutions and not judging everything by the standards of Washington DC. As Ostrom (2010, p. 642) has pointed out, “... the application of empirical studies to the policy world leads one to stress the importance of fitting institutional rules to a specific social-ecological setting. 'One size fits all' policies are not effective".

The general acceptance of the importance of institutions in determining the course of the transition process, led to extensive empirical work, both descriptive and econometric. An example of the latter is the investigation of labour market institutions in transition countries by Lehmann and Muravyev (2012). This suggested, inter alia, that active labor market policies can be very effective in reducing youth unemployment.

An important development in the FSU was the demonstration that, when the institutions necessary for an efficient market economy are lacking, just destroying the institutions of the old system and hoping that market-friendly institutions will emerge spontaneously, can have serious adverse consequences. As Polishchuk (1997) explained, the absence of adequate market institutions not only leads to rent-seeking behavior by individuals and firms but can also lead to the creation of new institutions that are incompatible with a market economy. A good example is the mutual nonpayment of bills that emerged in Russia in the 1990s. This was an economic institution, in that for a time it was widely regarded as an appropriate and acceptable form of behavior. For a period the state itself participated, refusing to meet its obligations to employees and suppliers. Non-payment was an ingenious and successful survival 
mechanism for an economy which, due to a combination of adverse circumstances, was not viable under conditions of normal payments discipline (Ellman, 2006, pp. 7-8). However, it was a non-market institution which was incompatible with a market economy. It was only undermined when a sharp currency depreciation, a reduction in capital flight, and an increase in world prices for oil and natural gas, made firms that paid their bills on time viable, and increased the state's income from taxation.

Hence it can be seen that an important result of theoretical reflection on the transition process was to stress that mainstream economic theory was not very well suited to analyse transition. The focus of mainstream economics is on rational individuals and firms maximizing their possibilities in a stable market economy. This implicitly assumes that all institutions are given exogenously. Hence, it is only partially relevant to transition, a situation in which the main economic institutions are rapidly changing ${ }^{7}$. Similarly, Keynesian economics is largely concerned with the instruments a wise government interested in the welfare of society can use to temper fluctuations in economic activity but has little to say about the nature of economic institutions and their change over time. It was obviously not very relevant for policy purposes in Russia in the mid-1990s. At that time Russia had a "unique quasi-state, all the elements of which are pursuing only private or group interests" (Leontiev, 1994, p. 159). When considering transition, much attention must be given to institutionbuilding and avoiding possible negative consequences of an institutional void. Failure to do this has the effect of extending the transition period and reducing performance

\footnotetext{
${ }^{7}$ The limitations of neoclassical growth theory were fully recognized by two founders of the DSGE (Dynamic Stochastic General Equilibrium) research program (Kydland and Prescott, 1996 p. 72). They argued that neoclassical growth theory was useful in answering some questions but "fails spectacularly when used to address economic development issues". Since the purpose of theory in the DGSE research program is not faithfully to represent reality in all its complexity but to provide an input into an experiment that is able to answer some quantitative question, the fact that it is unable to answer all such questions is inevitable and not a fatal flaw. However, it does mean, that even according to its leading advocates, it is not relevant for many questions. One of them is transition.
} 
along the way. Furthermore, there is no unique set of perfect institutions. Effective institutions have to build on local history and conditions.

After examining the role of economics in the Russian catastrophe of the 1990s, a recent book on economic methodology concluded that (Backhouse 2010, p. 50):

...whilst economists have had successes on a small scale, as in the US market for $\mathrm{SO}_{2}$ emissions, [and] designing auctions, they can provide much less useful guidance when dealing with problems that involve entire societies, the operation of which depends on a complex web of social and economic institutions. It may well be the case that there was neither the time to design institutions that would have made it possible to have [a] less catastrophic transition to capitalism nor the political power to put them into place, but it did not help that economics was dominated by abstract theories that paid scant attention to the institutions needed for capitalism to function properly.

\section{Path dependence}

The idea of path dependence was introduced into economics by David (1985). From a neoclassical point of view it was an anomaly, that is, a phenomenon that did not fit into the dominant paradigm. In a world of perfect foresight and optimization, there is no room for situations which require for their explanation a study of historical processes. Several authors (Hedlund, 2005; 2011; Brancato, 2009) have argued that, for understanding the Russian experience with transition, an understanding of Russian history is essential. Indeed these authors treat Russian economic development as primarily a path-dependent process, in which reforms aimed at fundamental institutional changes have repeatedly withered and died. This, in their view, explains why Russia is not a market economy and will not become one, despite the advice of the IFIs and the wishes of some section of Russian society.

Hedlund stressed the persistence of autocratic rule (tsars, general secretaries, presidents), the persistent gulf between the population and the state, the lack of the rule of law, the inability of the state to provide credible commitment, the priority of military security over material well-being, and the social norms that facilitated these 
phenomena. Brancato argued that today, as in the past, Russia is a country where hierarchies and networks, not market forces, determine resource allocation.

This perspective is not confined to Western authors. Oleinik (2011), too, completely accepts the role of path dependence in the Russian case. However, he stresses that history is not a fully deterministic process, and that veering away from the path, although difficult, is possible. The end of the Soviet system and the attention to the market was a major change and the current relations between the state and business were a result of conscious decisions and not fully predetermined. They were facilitated by stereotypes inherited from the past and the attitudes and ideas of the rulers and the population inherited from the past, but they were implemented by people who might have chosen to do something different.

It is indeed obvious that Russia's legacy of autocratic rule, imperial goals, priority of military objectives, and hostility to market forces, greatly influences the policy choices made and the behavior and ideas both of the rulers and of the general population. Nevertheless, some qualifications are in order. First, it is not the case that Russia's failure to become a Western society has caused a great disaster. Quite the contrary. Historically speaking, Russia has been a great success. Unlike other nonWestern societies it was not conquered by the West and in fact has been a great power since the 18th century. Attempts to conquer it by 'civilized Europe' in the persons of Charles XII, Napoleon, and Hitler were all a miserable failure. Furthermore, its abundant natural resources have generated, when world prices were favorable, abundant resources to finance domestic consumption, other state expenditures, and foreign investment. Present day Russia, with its dependence on exports of oil, natural gas and metals, generates the riches which can be seen on the streets of Moscow, the villas which surround many Russian cities, and the Mediterranean villas of its elite. The 'Russian disease' (Kuboniwa, 2012), i.e. the dependence of growth on world oil prices, makes Russia vulnerable to declines in world oil prices, but when they are high the income from the sale of oil and natural gas enables pensions and salaries to be paid on time, officials and businessmen with the right connections to accumulate large 
sums, and a rearmament program to be implemented. Secondly, a deterministic stress on the impossibility of creating a market economy in Russia ignores the important market elements in the economy, before 1914, in the 1920s, and since the collapse of the USSR. Russia today, for example, has a computer-virus protection company that sells its services internationally and competes successfully on the world market.

Nevertheless, the striking continuities in Russian history do suggest that this is a case where path dependence has been very important in determining and maintaining an economic system which even today is far from being a textbook market system.

\section{Holistic social engineering ${ }^{8}$}

In his influential and widely-read books, The Open Society and Its Enemies and The Poverty of Historicism, Popper argued against holistic or Utopian social engineering and in favor of piecemeal social engineering (or to use another terminology, against revolution and in favor of reform). In many respects the transition is an example of precisely the kind of holistic social engineering that Popper attacked. Neoliberals, armed with their doctrines and sure that they were right, attempted to rebuild entire societies quickly according to a blueprint, the Washington Consensus (Williamson, 1989; 1994). Unlike what Popperians expected, holistic social engineering in a number of countries has turned out to be quite successful. Despite macroeconomic and social problems, in those countries capitalism has been built and the countries concerned have 'returned to Europe'. This indicates that there are two types of holistic social engineering: Utopian and imitative.

Utopian holistic social engineering attempts to reconstruct society according to a blueprint which exists in the minds of the movement doing the engineering but which has never existed in any actual society, and may be unfeasible. Popper's critique remains valid in this case. Imitative holistic social engineering, on the other hand, attempts to reconstruct society by taking over more or less completely the

\footnotetext{
${ }^{8}$ This section is a development of part of Ellman (1997).
} 
institutions and policies which actually exist somewhere else and are successful there. Although some aspects of Popper's critique are also valid in the latter case, experience in the transition has shown that, under certain conditions, this type of holistic social engineering is feasible. Furthermore, writers such as the Polish Minister of Finance in 1989-1991 Balcerowicz (e.g. Balcerowicz et al., 1997) have argued that it is advantageous since, at moments of regime change ('extraordinary politics') there is a 'window of opportunity' (Roland, 1994; Frydman and Rapaczynski, 1997: Roland, 2000, chapter 2) which makes it possible to do quickly what at other times would be difficult and lengthy to implement.

However, as a result of the different experience of Poland and Russia, Russian economists tend to view the matter differently. In a paper prepared for a conference in Moscow in 2005, partly sponsored by the World Bank and IMF, Kuz'minov et al (2005, p. 5) argued that:

In the initial period of reform in Russia a pretty radical economic outlook was widespread, according to which it is possible at a rapid rate to reconstruct the institutional structure of society if one displays sufficient political will and acts rationally, selecting the most efficient institutions. Today we understand that the attempt at such a revolutionary institutional break led to contradictory results. Alongside positive changes there were many unforeseen consequences, the social costs of reform were too high, and we were unsuccessful in achieving the desired spurt in economic development.

They concluded (Kuz'minov et al., 2005, pp. 75-82) that in reforming Russian institutions it was necessary to give less weight to imports from abroad and more weight to cultivating reforms that fitted in with Russian conditions, take account of the economic and social behavior of economic actors, conduct economic experiments, engage in wide public discussion, and commission a variety of proposals for new measures before adopting any one of them. They rejected the model of a small group forcing through a law or decree based on experience in some other country, without attention to what its effects were likely to be under Russian conditions. In this way 
they applied the Popperian critique of holistic social engineering also to the imitative variant.

\section{The importance of banks and financial fragility}

Nowadays, everyone is aware of the crucial importance of the banking system for economic stability and economic growth and the need to take measures to deal with financial fragility. The role of banks in the transition process currently receives due attention in the academic literature on transition (e.g. Bonin and Schnabel, 2011). The need to prevent financial fragility destabilizing the economy and precipitating recession or depression is currently obvious to all central bankers and bank regulators. Although peripheral in the fashionable DSGE approach to macroeconomics ${ }^{9}$, the world economic crisis has made the importance of banks in a market economy very obvious to everyone interested in economic policy. However, in the initial discussion of transition, the need to establish a banking system that contributed to economic stability and economic growth received little attention. An exception to this was Brainard (1991). Experience soon showed that the banks play a very important role in the transition. They provide (or fail to provide) the payments transmission system. They can - if prudently managed by fit and proper persons ${ }^{10}$ - provide a home for the

\footnotetext{
${ }^{9}$ Kydland and Prescott (1996, p. 83) pointed out that "With the general equilibrium approach, empirical knowledge is organized around preferences and technologies". Since capitalism is based on firms, money, the state, the market, and inherited inequality, intuitively it seems unlikely that the general equilibrium approach will be very relevant for understanding it, even though preferences and technologies are of course important in capitalism. As Leijonhufvud (1973, p. 337) long ago observed, "It is true that virtually all Econographers agree that present modl-making has reached aesthetic heights not heretofore attained. But it is doubtful that this gives cause for much optimism". However, the DSGE research program has been successful in providing exercises for graduate students and employment for economists.

${ }^{10}$ A leading Russian 'banker' was asked after the Russian financial crisis of 1998 whether he felt any guilt about the losses of depositors in his bank. He replied that people who had been so foolish as to trust him deserved the losses they had experienced.
} 
cash surpluses of businesses and short- or long-term savings, which is safer, more convenient, and more lucrative than dollar notes, domestic currency notes, or tangibles. They provide (or fail to provide) loans to individuals, businesses and the state. Their loans may play a major role in financing investment (where profits are inadequate and/or the capital market is unable or unwilling to provide finance). They can also play a positive role in the work-out of overdue loans (as in Poland in the early 1990s).

However, experience has also shown that banks can also have a serious negative effect on economic development. The poor financial position of the banks, combined with the financing needs of the state, may make the banking system a way of channeling funds away from business investment (Abel and Bonin, 1993). Bad loans by banks may require recapitalization of the banks by the state, generating a fiscal burden (as happened in Hungary in the 1990s). Bad loans by banks may also generate a deep economic crisis (as in Bulgaria in 1996-1997). Poor supervision and regulation of banks may permit spectacular banking collapses (as happened in the Baltic countries and the Czech Republic in the 1990s). Fraudulent investment (often Ponzi) schemes have been a widespread problem, and in one country (Albania) even precipitated a national uprising.

One response to these problems was to allow the banking system to be taken over by Western banks. In this way it was hoped to place the banking system on solid foundations, since Western banks were assumed to be experienced in the ways of a market economy, and to conduct their affairs cautiously and prudently. However, this caused new problems. Western banks, interested in growing their market share and matching their own assets and liabilities, sometimes sold on a large scale mortgages denominated in foreign currencies. Initially these seemed attractive to customers because of their relatively low interest rates. However, if the domestic currency then depreciated relative to the currency in which the loans were denominated, as happened in Hungary, then owners of residential property found themselves confronted by rising debts, rising interest payments, falling after-interest incomes, and actual or threatened bankruptcy. Furthermore, the pressure on the Western banks to deleverage after the 
world economic crisis of 2008-2009 made them reluctant to expand the loans of their subsidiaries in Central and Eastern Europe and encouraged them to withdraw from this region. This limited growth in those countries where the banking sector was dominated by Western banks.

\section{The need for economic policy to take account of structural and country- specific factors}

Obviously economic policy is very important in determining outcomes. An example is the 'open door' policy adopted by China in the 1990s which has contributed significantly to its prolonged high economic growth. However, this was only possible because of a number of positive structural factors - the existence of a large and entrepreneurial Chinese diaspora prepared to invest in China; a long sea border which provided access to the world market; a low initial development level which provided huge 'catch-up' possibilities; unlimited supplies of labor (Lewis, 1954); and a reasonably stable and effective political system. Hence, a country lacking these features, e.g. a land-locked Central Asian country such as the Kyrgyz Republic, would be unlikely to do as well if it too adopted an open door policy. Nevertheless, international economic agencies traditionally stress policy, have standard policies which they recommend everywhere, and expect their policies - if adopted - to work successfully in all countries ${ }^{11}$. This ignores the major structural differences between countries. For example, in December 1989, Yugoslavia introduced a radical stabilization plan of the type supported by the IMF. The initial experience seemed

\footnotetext{
${ }^{11}$ However, a recent World Bank book (Yusuf, 2009, p. 55) did recognize that policies of the type recommended by the World Bank have little effect in accelerating growth, and cited academic research which suggests that growth is mainly a function of history and shocks. On the same page, the author recognized that state investment or state-directed investment was dominant in a number of high-growth Asian countries. Nevertheless, for the World Bank, armed with many examples of inefficient public investments, this was not, and is not, an attractive path but rather a risky or wasteful one.
} 
favorable, and in April 1990 the IMF concluded that (IMF, 1990, p. 127) “...Yugoslavia's prospects for noninflationary growth in the medium run, with external viability, appear to be good". What this conclusion ignored was the specific situation in Yugoslavia. Whereas in some countries the program might have worked, in the situation of tension and distrust between the constituent republics of Yugoslavia, the implementation of this program was unfeasible, and the attempt to implement it contributed to the disintegration of the country and the subsequent wars.

For policies to be effective they must not only take account of the relevant structural factors but also utilize those features of the country concerned which give it potential opportunities for economic growth and human development. Location, demography, politics, size, disease, war, level of development, role of agriculture, and the extent of inequality, are all major factors determining the effectiveness - or otherwise - of economic policy. The role of structural and country-specific factors in generating a variety of possible successful development paths or determining the course of economic evolution is increasingly understood (Rodrik, 2007), and is something which the very varied experience of the transition countries has stressed.

It is noteworthy than in their interaction with Chinese policy advisers, the IFIs have been much more cautious and much more sensitive to local conditions than they were in Central and Eastern Europe and the FSU in the $1990 \mathrm{~s}^{12}$.

\section{Privatization}

The introduction of legal private trade, private production, and private ownership of means of production has brought many benefits to the population of the transition countries. For entrepreneurs it has brought the possibility of developing and marketing new products and processes. For workers it has brought a choice of employers. For consumers it has brought a much wider assortment of goods and services. However,

\footnotetext{
${ }^{12}$ This was long ago pointed out by Nolan $(1995$, p. 174). He ascribed it to the confidence of the Chinese leaders in their own approach and goals.
} 
the efficiency-raising effects which economists expected from the privatization of state-owned enterprises often did not materialize, at any rate in the short run. The liberal economist Yasin (2009, p. 466) concluded that in Russia "Without a doubt, privatization did not lead to increased efficiency of the economy". This conclusion was partly based on the careful econometric study of Brown, Earl, and Telegdy $(2006)^{13}$. It concluded that the effects of privatization of state-owned manufacturing enterprises on efficiency varied between countries and depended partly on the identity (domestic or foreign) of the new owners. Yasin (2009, p. 469) also noted that the receipts of the state from privatization were very small and concluded that on this criterion too the results of Russian privatization were "highly unsatisfactory". Furthermore, as a World Bank study has noted (Yusuf, 2009, p. 69) "for many countries - especially the transition countries unprepared for a wholesale transfer of assets - the costs of some types of privatization were high and deeply resented". In some countries privatization led to a dramatic polarization of society between a small very rich minority of politically well-connected people and a large impoverished part of the population. This is one of the explanations for the widespread nostalgia for the old system.

The mixed results of privatization and the ignorance of the IMF, World Bank, and other advisers who advocated its rapid implementation at the beginning of the

\footnotetext{
${ }^{13}$ The results of this study for Russia are sensitive to the values used for the capital stock. The paper uses data for 1985-2002. Since 1985-2002 was an inflationary period and in some years inflation was very rapid it is necessary to revalue the original data for the year concerned so as to arrive at a consistent series ('constant 2002 prices'). The use of incorrect revaluation coefficients (for example as a result of underestimating depreciation) may explain the "somewhat puzzling" (ibid, p. 67) large increase in the Russian capital stock in manufacturing in 1985-2002 shown by their data. (Reducing this increase would automatically increase measured productivity and hence the apparent efficiencyenhancing effects of privatization.) Furthermore, the paper does not seem to distinguish between the effects of privatization as such and the macroeconomic situation. The fall in output in Russia following privatization was not solely a result of privatization and may not have been a result of privatization at all.
} 
transition process has been fully recognized by the World Bank. Yusuf (2009) has noted that:

Few had anticipated how messy privatization in the transition economies would be and how uneven the outcomes. Sales to insiders at low prices, asset stripping, and "tunneling" diverted many of the state assets into well-connected hands with long-term consequences for income and asset distributions. Weak managerial capabilities, limited competition, and ineffectual regulation all conspired to limit the anticipated improvements. And inevitably, resistance from vested interests and the absence of credible private buyers meant that many assets remained in the public sector, as for instance, in China, Russia, and other Commonwealth of Independent States countries. On balance - and especially with respect to manufacturing enterprises - privatization was and is a sound idea. Its scope, pacing, and regulation were not well understood in the 1990s. The risks were underestimated, and the challenges of creating a workable regulatory infrastructure confounded newly formed governments and their foreign advisers. The obstacles to creating autonomous and effective regulation have proven to be highly recalcitrant in both developing and developed countries, and the experience with privatized utilities is definitely mixed.

It was not only experience with utilities that was "definitely mixed". The same applies to natural resources.

Privatization was initially discussed exclusively in terms of privatizing stateowned enterprises, whereas what turned out to be very important was the development of de novo enterprises. Case studies of de novo enterprises in eight transition countries showed that (Aidis and Welter, 2008, p. 8):

Even though the transition process was a source of many challenges for these entrepreneurs, especially in the early stages of transition in terms of the weak institutional environment, instability of regulation, excessive government interference, corruption and so on, it also provided tremendous opportunities for innovation, business development and growth that are unparalleled in mature market economies.

However, only a few of the very large number of newly registered private enterprises are dynamic entrepreneurial organizations of the Schumpeterian type. A well-informed analysis of the small private sector in Hungary, Slovakia and the Czech Republic 
(Rona-Tas, 2001) drew attention both to the rapid growth of the number of new enterprises and of the proportion of the labor force working in them, and also to a variety of negative aspects of this process (little accumulation, low levels of capitalintensity and technology, a segmentation of the economy, weak regulations, lack of cooperation and associated public goods issues, and an increase in the size of the informal sector). Many of those working in the new small private sector are people who lost their jobs in the state sector and exploit their existing skills as self-employed. This provides the people concerned with an income, but is not comparable to the creation of Apple, Google or Microsoft. A significant proportion of actual and potential entrepreneurs have found the economic climate in the transition countries inhospitable and migrated to countries such as Israel or the USA which are more entrepreneur-friendly.

Furthermore, advice immediately to privatize state-owned enterprises and leave it to the new owners to restructure them ignored the fact that the restructuring of state-owned enterprises was frequently possible and the sale of restructured enterprises could generate substantial revenue for the state. Moreover, rapid privatization and closing of unprofitable (at world market prices) enterprises - even when they generated a positive value added - could lead to substantial unemployment and disguised unemployment (e.g. in subsistence agriculture), leading to a fall in overall labor productivity in place of its expected increase.

A significant mesoeconomic issue for privatization was agriculture. In most countries the reformers inherited a statized agriculture and sought to transform it along lines suggested by the IFIs. The outcome differed significantly from the initial expectations ${ }^{14}$. Western advisers (and some domestic reformers) expected that agricultural reform would lead to the end of shortages (as disequilibrium prices were eliminated), more output (as the inefficient communist system was abolished), the collapse of large-scale agriculture (as the political support for it was overthrown) and

\footnotetext{
${ }^{14}$ The following paragraphs on agriculture are partly a repetition of Ellman (2003b, pp. 1-2). See also Bezemer (2001) and Visser (2008).
} 
the emergence of a dominant family-farming sector (the natural kind of agricultural organization in a market economy).

Shortages of food products did generally disappear, but this was partly due to a reduction in domestic demand resulting from falling real incomes and partly a result of an increase in food imports. Far from increasing as a result of eliminating the 'inefficient Communist system' agricultural output normally fell. Large-scale farming did not rapidly disappear as the political support for it was removed. In fact it proved remarkably resilient. Family farming did not everywhere become the dominant form of agriculture. Both the former private plots (often enlarged under the new conditions) and large-scale farming remained important. This was not just a matter of inertia and path dependence. By 1995, in the former East Germany, there appeared to be no efficiency advantage to family farms compared with large-scale farming (Mathijs and Swinnen, 2001). In Russia family farming remained marginal after two decades of reform. In 2009, seventeen years after the destruction of the USSR, $45 \%$ of the output of Russian agriculture came from large-scale farm enterprises, $47 \%$ from household production (of which a large proportion was for subsistence or barter) and only $8 \%$ from the small-scale family farms thought 'natural' by Western advisers ${ }^{15}$. In some areas of Russia there was a 'haciendaization' of agriculture, with the transformation of the old collective farms into institutions resembling the Latin American hacienda ${ }^{16}$.

Not only were expectations not completely fulfilled, but there were a number of striking unexpected results. These concerned technical regress, subsistence agriculture, barter, and the tenacity of old forms and networks.

The old system made extensive use of machinery and chemicals (e.g. artificial fertilizers, pesticides). As a result of the worsening terms of trade of agriculture this often proved impossible for the new 'marketized' agriculture. Hence in many

\footnotetext{
${ }^{15}$ The World Bank (1992, p. 77) envisaged that by the end of 1995 about $40 \%$ of agricultural land would be farmed privately. Actually, even fourteen years later, in 2009, the proportion of the sown area farmed by family (or individual) farmers was only $20 \%$.

${ }^{16}$ For an example of one such case see Nikulin (2002).
} 
countries there was a revival of pre-industrial technology (e.g. the horse in Russia) and a growth in labor-intensity. Although part of the decline in the consumption of chemicals and machinery was economically rational and led to an increase in their productivity, part of it was simply technical regress resulting from the poor financial position of agriculture. Subsistence agriculture, a pre-capitalist phenomenon, turned out to be remarkably important and persistent. In many countries it became a major form of food production. A very striking phenomenon was the growth and importance in agriculture - mainly in the FSU - of barter. The exchange of food products for other food product, agricultural inputs or manufactured goods, was widespread in the FSU in the 1990s. Another unexpected development was the tenacity of old forms and networks. Not only did many of the former collective and state farms refuse to disappear completely as expected by their enemies. Also personal networks inherited from the old regime remained important. Old networks in rural areas frequently persisted as their members helped each other.

These differences between the initial advice and expectations about reforming agriculture and the outcome show the limited knowledge of the reformers and their advisers (both foreign and domestic) about agriculture and rural society and how they would react to change. Furthermore, it showed clearly that for many reformers ideology was more important than knowledge. There was inadequate attention in the initial policy proposals to the inability of many local authorities to provide the services previously provided by large farms ${ }^{17}$; to the lack of forward and backward market linkages, the need to develop them, and the time and resources that this would cost; to the indivisibility of many farm assets; to geography; to the peculiarities of particular

\footnotetext{
${ }^{17}$ In 1992 the World Bank (1992, p. 11) stated that "The restructuring of farms will require that the quasi-governmental and social service functions of state and collective farms be transferred to local and municipal governments." Ten years later Nikulin (2002, p. 363) pointed out that this was not yet feasible. "In civilized rural regions the services necessary for a rural community [e.g. schools, roads, clinics, shops] should logically be provided by local authorities and cooperatives. Real organizations of this type, with real authority and resources, hardly exist at the present time in Russian rural areas."
} 
crops and animals; and to the attitudes and wishes of the rural population. As Wegren (1998, pp. 112-113, footnotes omitted) observed of the situation in Russia in the mid 1990s:

The pretext for farm privatization was greater economic efficiency, but the "efficiency argument" became a cover for the ideologically driven goal of privatization for political purposes. As time passed the post-Soviet regime in Russia moved away from the question, How do we make agriculture more productive and efficient? to the question, How do we destroy rural institutions that are ideologically anathema? Because state and collective farms were relics of the Stalin era, they were ideologically anathema. Only in the realization of the "moral imperative" to destroy those farms could Russian agriculture throw off the chains of Soviet history.

\section{The importance of social policy}

One of the most striking initial results of the transition was a dramatic deterioration in the social situation in some countries (notably in the FSU, Romania, and Bulgaria), as indicated by processes such as impoverishment, declining employment, growth of unemployment, increased inequality, deterioration of public services and polarization of their provision, spread of disease, criminalization and growth of corruption, and the decline in such social indicators as life expectancy and school attendance (Ellman, 2000a; 2000b). This was particularly embarrassing for institutions such as the World Bank which played an important role in providing initial policy advice but which was officially committed to a global anti-poverty agenda.

As a result it became obvious that social policy was an important area to which attention should be directed. Unfortunately, some of that attention, such as the stress by the World Bank on the merits of funded pension schemes, turned out to be not very helpful. In neither Russia nor China has World Bank advice about pensions been a success. As Fomin (2011, p. 86) wrote about the Russian reform twenty years after it was initiated, "the pension reform did not give the expected results". Employers' social security contributions only covered about half the expenditure of the pay-as-you 
go pillar (this was partly a result of widespread evasion of social security contributions), so that about half had to come out of general taxes. The funded pillar was not dominated by private investment managers - almost all employees paid into the state Pension Fund. The funded pillar, under adverse macroeconomic conditions (high inflation and economic crises in 1998 and 2008-2009) earned negative real rates of return ${ }^{18}$. The main problems of the inherited Russian pension system were not that it relied on pay-as-you-go, but its low retirement ages (55 for women and 60 for men with earlier retirement ages for workers in certain regions and occupations ${ }^{19}$ ) which it would be very unpopular to raise, and low average replacement rate, which it would be very expensive to increase ${ }^{20}$.

Similarly in China the pension funds had difficulties in collecting pension contributions in the private sector, and in earning a positive real rate of interest, and the rate of growth of money wages has been greatly in excess of the rate of interest, so that funding was of little benefit. In China a major difficulty in introducing a national pension system was the substantial differences in income and social conditions between urban and rural areas. Hence the pension reforms of the 1990s were confined to urban employees. They were hindered by the differences between different parts of

\footnotetext{
${ }^{18}$ In 2004-2010, a period which included both a financial crisis and a recovery, the average real return on funded pension assets of state investment managers was $-0.44 \%$ p. a., and of private investment managers - $0.17 \%$ p. a. (Fomin, 2011, p. 88).

${ }^{19}$ Shiriaeva (2012, p. 85) has stated that these early pensions in 2010 were $2.5 \%$ of the GDP. The majority of the recipients of early pensions carry on working at least till the normal retirement age. According to one estimate (cited in Fomin, 2012, p. 15) the result of early pensions is that the average age of first receiving a pension is 54 for men and 52 for women. Tackling early pensions has been repeatedly mentioned in official documents but nothing has been done about it in view of the unpopularity of such a measure. The possibility of eliminating pensions for people who carry on working has been discussed in the academic literature. However, as Shiriaeva (2012, p. 86) has pointed out, it would be difficult to implement this in Russia because of the high share of the informal sector in total employment.

${ }^{20}$ The low average replacement rate partly results from the wide dispersion of earnings. If the highest incomes are excluded from the calculation the replacement ratio rises significantly.
} 
the country, and the differences between different types of employer (state-owned, foreign-invested, domestic private, etc) and different types of employee (permanent, temporary, part-time, with or without urban registration). It seems that in 2004-2005 only about $50 \%$ of urban employees were actually covered by the pension system (Frazier, 2006, p. 48). In addition, social security contributions have been inadequate to cover the pay-as-you-go outlays requiring a contribution from general taxation. Furthermore, the intended savings in the funded pillar have generally not been accumulated but spent on current outlays by local governments, leaving the authorities with a rapidly growing unfunded debt.

Likewise, the introduction of compulsory medical insurance in Russia in 1993, approved and supported by Western 'experts', failed to achieve its objectives (Davis, 2001; Ol'khovskii and Tikhonov, 2010). The money available to the medical system did not increase; the health status of the population did not improve; and inequalities in access to health care and in health outcomes did not decline.

Similarly, some of the criticism by World Bank economists of inadequate targeting of transfer payments was also inadequate. For example, World Bank economists in the 1990s tended to argue that Russian social policy was inefficient, because a high proportion of the transfer payments went to the non-poor. However, Clarke (1999) pointed out that this was misleading. The reason for this situation was that pensions were a large part of transfer payments, and pensions were still sufficient to keep most pensioners above the (very low) poverty line. Hence, the fact that most transfer payments were made to the non-poor simply showed how effective pensions can be in keeping people out of poverty.

The obvious social ills and need to tackle them, and the difficulties and failures of some initial reforms, led to renewed attention to social policy. This led to a revived stress on employment creation, the provision of quality education, health care and housing, and the provision of pensions and other transfer payments (Eatwell et al., 2000). These desirable and important goals naturally had to take account of fiscal realities, and the need to provide incentives for individuals and firms. 


\section{The importance of objectives}

The idea propagated by some economists and international organizations that all the countries from the Baltic and Central Europe to the South China Sea were 'transition countries' with similar goals was a profound illusion. The transition countries have had very different objectives. In Central Europe the goal was to 'return to Europe'. This meant developing a democratic political system and a capitalist economy. Countries such as Poland and Hungary have been successful in these goals. Politically they have had an alternation in power of different political parties, as a result of elections. Economically, they are now capitalist economies of the European type, i.e. with considerable welfare expenditures and a substantial state role in the economy. In the FSU the goals were to end the rule of the former all-Union Communist party and replace it by rule by local elites, enrich the local elites by looting the national economy, and create an economic system with substantial market elements (in particular imported consumer goods). These goals have all been achieved. In China the goal was to preserve the power of the Communist party and achieve rapid economic growth. These goals too have been achieved.

Attention to these different goals and their importance was long ago drawn by Pomfret (1997). Slovenia, Estonia, Latvia, Lithuania, Poland, the Czech Republic, Slovakia, and Hungary are democratic capitalist economies and members of the European Union. They have succeeded in breaking decisively with Communism. This has been both a great success and a disappointment to many of those living through this process (Kornai, 2006; Sanfey and Teksoz, 2007) ${ }^{21}$. China has become the workshop of the world, and its prolonged high growth is the envy of the world. However, it remains a Communist dictatorship. It has not made the transition to democracy, and shows no signs of doing so. Nor has it made the transition to

\footnotetext{
${ }^{21}$ According to the Pew surveys, in the FSU experience of capitalism has led to a steady decline in its popularity (Confidence, 2011). In the 2011 survey, only $34 \%$ of respondents in Ukraine, $42 \%$ in Russia and $45 \%$ in Lithuania supported the change to a market economy. In Ukraine 51\% disapproved, in Russia 45\% disapproved, and in Lithuania 35\% disapproved.
} 
capitalism. Given the size and significance of the role of the state in the economy it can better be described as market socialist (Gabriele, 2010).

\section{Economic rent and its (mis)uses}

The 'new political economy'/public choice school of Buchanan, Tullock and others rightly drew attention to the importance of economic rent. However, it treated it primarily as a source of social waste, to be dealt with by reducing state discretion, and expanding the role of market forces. However, the transition has shown that this is just one aspect of the phenomenon. Economic rents can also be valuable resources which can be put to socially positive uses.

In both Russia and China discretionary decisions by government officials have generated substantial economic rents. Part of these rents have been syphoned off by corrupt officials in the form of personal consumption or foreign investment (typically in bank accounts or real estate). However, part has been used for economic and social development. In China provincial/municipal/local officials have been judged largely on the economic development of their regions. Hence, they have had a strong incentive to stimulate the development of their region. This has led to the combination of a national developmental state with numerous regional developmental states, which has played a key role in China's rapid economic growth ${ }^{22}$. Not only have economic rents stimulated economic development, they have also strengthened state capacity. Officials have been able to use them to undertake initiatives that would have been too expensive without them. Furthermore, they have has provided a social basis for the whole reform process - the combination of officials personally involved in and benefiting from economic development, the firms that benefit from rents that they

\footnotetext{
${ }^{22}$ For an example, the Kunshan Economic and Technical Development Zone near Shanghai, see Ellman (1998). The conclusion of this article was that "The success of China's Kunshan Development Zone shows that local state entrepreneurship can play an important positive role in economic development".
} 
secure from one or another level of government, the workers who enjoy expanded employment opportunities, and the beneficiaries of extra social expenditures.

It is often asked how a country such as China which fares so badly on Transparency International's corruption indicators and other good governance indicators can nevertheless grow so quickly. The answer is simple. The same developmental state (both central and local), which has up till now successfully guided China's economic development, is simultaneously responsible for creating the opportunity for massive corruption. Hence, a successful anti-corruption drive would undermine both the developmental state and the social basis of economic reform. However, the corruption generates widespread popular opposition to the authorities that may become politically important in the future.

As Ngo (2008, p. 42) has observed,

Contrary to what economists conceived of as social waste, economic rents can become valuable resources which state agents can create/manufacture by simply using administrative directives. Rent-creation and allocation can become a source of state capacity when being used as a policy instrument to guide national and local developments. At the same time, the capacity over rent-creation has generated strong incentives among state agents to support the market reform as well as to boost local economic development.

Rent-production is thus a source of state capacity, political acquiescence, and developmental incentive. Yet it is also a source of dire social problems. Rent-production [in China] under the prevailing framework of economic governance has provided a fertile ground for corruption. This is because policy discretions informing the allocation of rents are inevitably ad hoc and arbitrary. In a society characterized by informal relations of patronage, cronyism and nepotism, such official arbitrariness more than often ends up in corrupt exchanges. The combination of extensive state intervention, policy discretions, and profound clientelism thus produces a strong structural nexus between economic governance, rentseeking, and corruption. In the absence of any basic changes in economic governance, such structural nexus will defy administrative measures aiming at achieving a clean government in China. 


\section{The limitations of conventional policy advice}

The initial period of transition in Eastern Europe was marked by influential advice about what should be done from individual economists and from international organizations (backed up by loans and, in some cases, help with debt restructuring, and also the facilitation of export credits and trade finance). This advice was sometimes sensible (and accepting it helped with debt reduction and access to export credits and trade finance), but was often wrong or misleading (Gomulka, 1995; Ellman 2003a, pp. 191-196). In its input into both the Polish economic program of January 1990 and the Russian programme of January 1992 the IMF grossly underestimated likely corrective inflation. At the end of 1991 the IMF team suggested that, as a result of liberalizing prices, inflation in Russia in January 1992 would be 50\%. The Ministry of Finance thought it would be $100 \%$. The Economics Ministry estimated it about 200\%. Actually it was 245\%. The 'conservative' Economics Ministry (the former Gosplan) had been much more accurate than the 'scientific' IMF. The IMF also underestimated the likely fall in output in Poland in 1990. In all these cases, the effect of these errors was to make the policies of the IMF seem more attractive than they actually turned out to be. Furthermore, its initial position that a level of inflation of less than $1 \%$ per month is a requirement for the transition to a market economy also turned out to be wrong. Similarly, its initial support in 1991-1992 for the maintenance of the ruble zone had a substantial cost for Russia, and was politically not sustainable ${ }^{23}$. Its pressure in 1997 for the liberalization of the Russian capital account contributed to the crisis of 1998 and according to Stone (2002, pp. 147-148) was "the IMF's biggest tactical mistake in Russia". Moreover, its support for the ruble exchange rate in 19971998 had adverse effects on economic growth, facilitated capital flight, and required a state-organized Ponzi scheme to sustain it. The initial assumption that socialist enterprises would behave according to market principles also turned out to be wrong. The desirability, stressed by the IMF, of reducing very rapid inflation quickly, was

\footnotetext{
${ }^{23}$ For a discussion of this issue see Symposium (2002).
} 
obviously entirely sensible, where this was feasible and the costs not too high. However, a long period for reducing inflation to civilized levels was sometimes necessary, e.g in Poland (where it took ten years to reduce inflation to less than $10 \%$ p.a.). Given the circumstances, Poland's gradual stabilization was entirely sensible ${ }^{24}$.

In 1993 the World Bank advised the government of Uzbekistan (World Bank, 1993, p. xi) that, in the absence of comprehensive reforms, production would fall as a result of supply-side and foreign exchange constraints, and by 1997 per capita consumption would have fallen by at least $30 \%$. Actually the gradual transformation program implemented by the government of Uzbekistan led to one of the most favorable developments in production and consumption in the early and mid 1990s in all the FSU countries (this was partially the result of favorable prices for its chief exports). Saidova and Cornia (2005, p. 87) noted that "the experience of Uzbekistan in this area [taxation] differed perceptibly from that of other CIS countries as it avoided the revenue implosion and collapse in the provision of essential public goods and social safety nets suffered by many CIS countries". One reason for this was that Uzbekistan retained state control of the rent generated in the natural resource sectors (mainly cotton and gold) rather than privatizing them. The mistakes of the IFIs concerning privatization were discussed in Section 7.

These limitations in the provision of good policy advice ultimately derived from four facts. First, economics is a mixture of science and ideology. Secondly, economics is a subject in which much is written, but what is definitely known is limited. Thirdly, it is a policy-relevant subject which generates biases of its own. Fourthly, the IFIs and mainstream economics are biased towards the US model.

The relative importance of science and ideology in modern economics has been analyzed by Backhouse (2010). He pointed out that some parts of economics are

\footnotetext{
${ }^{24}$ According to Stone (2002, p. 114) Poland "is a clear example of the benefits of rapid macroeconomic stabilization." Given the very gradual process of macroeconomic stabilization in Poland in the 1990s this is a very odd statement. Polish macroeconomic stabilization was successful but it was not 'rapid'. Nor was its privatization of state-owned enterprises 'rapid'.
} 
scientific, combining theory with empirical verification. An example is the design of auctions. The use of modern economics when designing the auction process for the right to use radio frequencies enabled both the British and Dutch governments to receive billions of pounds/euros when they were sold. On the other hand, traditional microeconomics contains a large ideological element ${ }^{25}$. Hence the advice given to the transition countries at the beginning of the transition period had a substantial ideological component. Agriculture provides a good example of this.

One reason for the discrepancy between what is written and what is known is that economists - especially the most prestigious within the profession - know more about their models than about reality (Caballero, 2010). As a result, they tend to confuse propositions that are true within their models with propositions which are true in the real world. An important example of the ignorance of economists, despite their decades-long work on various models allegedly relevant for understanding and policyprescription, concerns development economics and its application to policy. Consider the efforts of the World Bank, using development economics to increase growth in the short to medium run. Easterly (2009, p. 131, references omitted) has argued that:

The intellectual tragedy of 30 years of World Development Reports (WDRs) is that they never accepted the reality of the great unpredictability and uncertainty of economic growth in the short to medium run. The WDRs keep trying to find ways to raise growth in the short to medium run when the economics profession does not have this knowledge. They seek to explain short-term fluctuations in growth when there is no evidence base for such explanations. As a result, they fall prey to many of the classic heuristic biases about

\footnotetext{
${ }^{25}$ For example, a US textbook of microeconomics (Kreps 1990: 200), after proving the First Theorem of Welfare Economics, commented that "You should now be hearing choirs of angels and choruses of trumpets. The 'invisible hand' of the price mechanism, produces equilibria that cannot be improved upon." With this heavenly blessing for the status quo students can forget about poverty, inequality and unemployment and be happy that they live in the best of all possible worlds. However, traditional microeconomics also contains a substantial scientific element. Allowing low-cost airlines to compete with the established airlines did benefit consumers. The basic tools of microeconomics (such as price and income elasticities of demand) have been useful in many applied fields.
} 
randomness (à la Kahneman and Tversky), including frequent use of circular reasoning, and they lose the opportunity to carry on a fruitful debate about the best way to handle this uncertainty and to make development more likely in the long run.

The ignorance of economists was unusually large in the initial transition period, because the quick creation of a market economy and democratic polity out of a bureaucratically managed economy and political dictatorship was a historically unprecedented phenomenon. Evidence-based policy recommendations could only be offered after considerable experience of what worked, what did not, and what caused the sharp differences between countries.

Because it is a policy-relevant subject, called upon to supply answers to urgent policy questions, practitioners are tempted to supply policy prescriptions even when the evidence for them is shaky or non-existent. The absence of evidence-based appropriate policies does not prevent individuals and organizations from advocating their favored policies. As Rodrik (2010) has noted:

Development economics is an applied, policy-relevant discipline, and as such is prone to get simplified and routinized in practice. The practitioner in an international organization or aid agency needs clear rules of thumb, not a lot of ifs and buts. When asked what to do, the mantras of 'import substitution' or of 'liberalize, stabilize, privatize' present a clear mandate for action. 'We don't know' and 'it depends' are unlikely to meet with equal enthusiasm.

Furthermore, standard policy advice is biased towards mainstream economics' vision of the USA, its present system and the path to it. This is partly because the IMF and World Bank are located in Washington DC, and are in close contact with the US government and New York financial interests. It is also partly because mainstream economics is dominated by the USA, which houses the most prestigious economists and institutions for training economists and the leading journals, and is the source of virtually all the new ideas within mainstream economics. As a result of these facts, the mainstream economist's idea of appropriate institutions is generally institutions similar to those existing or imagined to exist - now and in the past - in the USA. 
Given our ignorance, the role of ideology, and the dangers both of policy advocacy which is not firmly evidence-based and policy advocacy based on an idealized version of US practice, the Chinese practice of basing policy largely on the results of local experiments makes excellent sense. It is an alternative to the method favored by (non-experimental) mainstream economists of doing experiments on models and drawing policy conclusions from them. It is superior to the latter when the relevance of the model outcome for the economy is non-existent or highly uncertain and the local experiment is carefully monitored and its results unambiguous.

The IFIs, in particular the World Bank, do learn from experience, recognize their errors, and seek to correct them. Already in 1993 the former head of the World Bank's East European department concluded that "Eastern Europe is not well served by straight textbook advice" (van Wijnbergen, 1993, p. 35). A 2002 report prepared for the World Bank's own Operations Evaluation Department (Ellman, 2003, p. 195) concluded that the verdict on the Bank's activities in Russia up to the macro-economic crisis of 1998 could only be 'unsatisfactory'. The Bank's work at the project level was characterized as 'poor'. Its social protection programmes in the two areas deemed most important, pension reform and modernization of the labor code, were described as having 'failed'. However, some successes were recorded, such as its coal industry loans and an increase in oil production. Nevertheless, the overall impression was negative, and evaluation by an independent external body might well have been even more so. It should be noted that, if Western advice and loans are evaluated from the standpoint of advancing Western interests, rather than helping the Russian economy, the verdict would be more positive.

In the IMF too, there has been some rethinking in recent years.

The experience of the transition countries was one of the inputs that led to the Monterrey Consensus of 2002, paragraph 56 of which reads:

We stress the need for multilateral financial institutions, in providing policy advice and support, to work on the basis of sound, nationally owned paths of reform that take into account the needs of the poor and efforts to reduce poverty, and to pay due regard to the 
special needs and implementing capacities of developing countries and countries with economies in transition, aiming at economic growth and sustainable development. The advice should take into account social costs of adjustment programmes, which should be designed to minimize negative impact on the vulnerable segments of society".

\section{CONCLUSION}

The transition has greatly enriched our knowledge of economic processes. The transition process has demonstrated the need for an effective and accountable state and the dangers of state desertion. It has also shown the importance in economic life of institutions, path dependence, banks, and financial fragility. It has also pointed out the need to deepen Popper's analysis of holistic social engineering. It has made clear the need for effective economic policy to take account of structural and country-specific factors. It has shown that privatization is much more complex than many foreign advisers thought at the beginning of the transition process. In retrospect, they were rather ignorant about the methods, sequencing, and consequences of privatization, particularly of utilities, natural resources and agriculture. They neglected the possibility of restructuring prior to privatization and the fiscal gains from selling restructured firms. Experience has also shown that the effect of privatizing stateowned enterprises on efficiency varies, depending on the specific situation. It has also shown the importance for privatization of the de novo sector. The transition has also shown the importance of social policy, such as employment maintenance and creation, and the important role which public provision of medical care, education and transfer payments can play. It has also clarified the role which different objectives can play in generating different outcomes. It is not the case that political elites in all countries share the same goals.

In addition, the transition has shown that economic rents are not just a source of social waste and unjustified inequality. Under certain conditions they can be a source of state capacity, economic development and social expenditures. They may 
simultaneously provide a socio-political basis for economic reform and a ground for widespread opposition to the ruling authorities.

The transition has also demonstrated that it is not the case that the only viable destination for countries abandoning state socialism is a market economy of the US type, and that all the 'transition economies' will soon end up there. After two or more decades of transition ${ }^{26}$ they have arrived at a number of different destinations, ranging from dynamic market socialism (in China) via natural-resource-based capitalism with Russian characteristics (in Russia) to democratic European capitalism (in Central Europe).

Mainstream economic analysis and mainstream policy advice has already absorbed many of these lessons. However, when it has absorbed them, for example concerning the importance of institutions, it has sometimes interpreted them in a very one-sided way.

Conventional policy advice should not be unconditionally accepted in view of its past inadequacy, frequent attempts to prescribe uniform policies for very varied situations, our ignorance of many important issues, and the possible adverse consequences of accepting advice which is a response to public or political pressure for guidance on issues about which little is actually known.

Mainstream economics combines scientific and ideological elements. ${ }^{27}$ Much of the initial advice did not take adequate account of our ignorance, was not evidencebased, and contained a substantial ideological element.

\footnotetext{
${ }^{26}$ The exact period varies between countries.

${ }^{27}$ This was long ago pointed out by Joan Robinson (1962, p. 25), However, since her time economics has increased its scientific element (auction theory, experimental economics, behavioral economics, financial-crisis theory). The cooperation with psychology and the failure of the neoliberal paradigm have been particularly fruitful in the generation of new ideas and their acceptance.
} 


\section{References}

Abel, I. and J. P. Bonin (1993) State Desertion and Convertibility: The Case of Hungary, in I. P. Szekely and D. M. Newbery (eds.), Hungary: An Economy in Transition, Cambridge: Cambridge University Press.

Aidis, R. and F. Welter (eds.) (2008) The Cutting Edge: Innovation and Entrepreneurship in New Europe, Cheltenham: Elgar.

Backhouse, R. (2010) The Puzzle of Modern Economics: Science or Ideology? Cambridge: Cambridge University Press.

Balcerowicz, L., B. Blaszczyk, and M. Dabrowsk (1997) The Polish Way to the Market Economy, 1989-1995, in W. Woo, S. Parker, and J. Sachs (eds.), Economies in Transition: Comparing Asia and Eastern Europe, Cambridge, MA: MIT Press.

Besley, T. and T. Persson (2009) The Origins of State Capacity: Property Rights, Taxation and Politics, American Economic Review, Vol. 99, No. 4, pp. 1218-1244.

Bezemer, D. (2001) Structural Change in the Post-Socialist Transformation of Central European Agriculture, Amsterdam: Tinbergen Institute.

Bonin, J. and I. Schnabel (2011) The Great Transformation: From GovernmentOwned to Foreign-Controlled Banking Sectors, Economics of Transition, Vol. 19, No. 3, pp. 397-405.

Brainard, L. (1991) Strategies for Economic Transformation in Central and Eastern Europe: Role of Financial Market Reform, in B. Blommestein and M. Marrese (eds.), Transformation of Planned Economies: Property Rights Reform and Macroeconomic Stability, Paris: OECD.

Brancato, E. (2009) Markets versus Hierarchies: A Political Economy of Russia from the 10th Century to 2008, Cheltenham: Elgar.

Brown, D., J. Earle and A. Telegdy (2006) The Productivity Effects of Privatization: Longitudinal Estimates from Hungary, Romania, Russia and Ukraine, Journal of Political Economy, Vol. 114, No. 1, pp. 61-99. 
Brunetti, A., G. Kisunko, and B. Weder (1997), Institutions in Transition: Reliability of Rules and Economic Performance in Former Socialist Countries, World Bank Policy Research Working Paper, No.1809.

Caballero, R. J. (2010) Macroeconomics after the Crisis: Time to Deal with the Pretense-of-Knowledge Syndrome, Journal of Economic Perspectives, Vol. 24, No. 4, pp. 85-102.

Chang, H-J. (2011) Institutions and Economic Development: Theory, Policy and History, Journal of Institutional Economics, Vol. 7, No. 4, pp. 473-498.

Clarke, S. (1999) Poverty in Russia, Problems of Economic Transition, Vol. 42, No. 5, pp. 5-55.

Confidence (2011) Confidence in Democracy and Capitalism Wanes in Former Soviet Union, Washington, DC: PewResearchCenter,

http://www.pewglobal.org/2011/12/05/confidence-in-democracy-and-capitalismwanes-in-former-soviet-union/, accessed 8 May 2012.

Crouch, C. (1986) Sharing Public Space: States and Organized Interests in Western Europe, in J. A. Hall (ed.), States in History, Oxford: Blackwell.

David, P. (1985) Clio and the Economics of QWERTY, American Economic Review, Vol. 75, No. 2, pp. 332-337.

Davis, C. (2001) Russia's Compulsory Medical Insurance Reform, Department of Economics, Oxford University (unpublished report).

Easterly, W. (2009) The Indomitable in Pursuit of the Inexplicable: The World Development Reports' Failure to Comprehend Economic Growth Despite Determined Attempts, 1978-2008, in Yusuf (2009).

Eatwell, J., M. Ellman, M. Karlsson, D. M. Nuti, and J. Shapiro (1995) Transformation and Integration: Shaping the Future of Central and Eastern Europe, London: IPPR.

Eatwell, J., M. Ellman, M. Karlsson, D. M. Nuti, and J. Shapiro (2000) Hard Budgets, Soft States: Social Policy Choices in Central and Eastern Europe, London: IPPR. 
Ellman, M. (1997) The Political Economy of Transformation, Oxford Review of Economic Policy, Vol. 13, No. 2, pp. 23-32.

Ellman, M. (1998) China's Development Zones - Learning from Their Success, Transition: The Newsletter about Reforming Economies, Vol. 9, No. 6, pp. 6-7.

Ellman, M. (2000a) The Russian Economy under El'tsin, Europe-Asia Studies, Vol. 52, No. 8, pp. 1417-1432.

Ellman, M. (2000b) The Social Costs and Consequences of the Transformation Process, Economic Survey of Europe, No. 2/3 (2000), UNECE.

Ellman, M. (2003a) Transition Economies, in H-J. Chang (ed.), Rethinking Development Economics, London: Anthem.

Ellman, M. (2003b) Expectations and Reality: Reflections on a Decade of Agricultural Transformation, in M. Spoor (ed.), Transition, Institutions and the Rural Sector, Lanham: Lexington.

Ellman, M. (2006) The Issues, in M. Ellman (ed.), Russia's Oil and Natural Gas: Bonanza or Curse? London: Anthem.

Ferraz, C. and F. Finan (2011) Electoral Accountability and Corruption: Evidence from the Audits of Local Governments, American Economic Review, Vol. 101, No.4, pp.1274-1311.

Fomin, D. (2011) Itogi reformirovaniia i perspektivy pensionnoi sistemy Rossii: vmesto poslesloviia, EKO, No.3, pp. 86-91.

Fomin, D. (2012) Starost', ekonomika, demografiia, EKO, No. 4, pp. 5-25.

Frazier, M. (2006) Pensions, Public Opinion, and the Graying of China, Asia Policy, No. 1, pp. 43-68.

Frydman, R. and A. Rapaczynski (1997) Corporate Governance and the Political Effects of Privatization, in S. Zecchini (ed.), Lessons from Economic Transition, Dordrecht: Kluwer.

Frye, T. (2010) Building States and Markets after Communism, Cambridge: Cambridge University Press. 
Gabriele, A. (2010) The Role of the State in China's Industrial Development: A Reassessment, Comparative Economic Studies, Vol. 52, No. 3, pp. 325-350.

Gomulka, S. (1995) The IMF-Supported Programs of Poland and Russia, 1990-1994: Principles, Errors and Results, Journal of Comparative Economics, Vol. 20, No. 3, pp. 316-346.

Grogan, L. and L. Moers (2001) Growth Empirics with Institutional Measures for Transition Countries, Economic Systems, Vol. 24, No. 4, pp. 1-22.

Hedlund, S. (2005) Russian Path Dependence: A People with a Troubled History, Abingdon: Routledge.

Hedlund, S. (2011) Invisible Hands, Russian Experience, and Social Science: Approaches to Understanding Systemic Failure, Cambridge: Cambridge University Press.

IMF (1990) Yugoslavia Launches Bold Reforms to Combat Hyperinflation, IMF Survey, Vol. 19, No. 8 (16 Apr. 1990), pp. 124-27.

Intriligator, M. (1996) Reform of the Russian Economy: The Role of Institutions, International Journal of Social Economics, Vol. 23, No. 10/11, pp. 58-72.

Ito, T. (2009) The Evolution of Development Economics and East Asia's Contribution, in Yusuf (2009).

Kornai, J. (1994) Transformational Recession: The Main Causes, Journal of Comparative Economics, Vol. 19, No. 1, pp. 39-63.

Kornai, J. (2006) The Great Transformation of Central Eastern Europe: Success and Disappointment, Economics of Transition, Vol. 14, No. 2, pp. 207-244.

Kreps, D. (1990) A Course in Microeconomic Theory, New York: Harvester Wheatsheaf.

Kuboniwa, M. (2012) Diagnosing the 'Russian Disease': Growth and Structure of the Russian Economy, Comparative Economic Studies, Vol. 54, No. 1, pp. 121-148. 
Kuz'minov, Ya. I., V. Radaev, A. Yakovlev, and E. Yasin (2005) Instituty: ot zaimstvovaniia $k$ vyrashchivaniiu: opyt rossiiskikh reform vozmozhnoe kul'tirovanie institutsional'nykh izmenenii, Moscow: Higher School of Economics.

Kydland, F. E. and E. C. Prescott (1996) The Computational Experiment: An Econometric Tool, Journal of Economic Perspectives, Vol. 10, No. 1, pp. 69-85.

Lehmann, H. and A. Muravyev (2012) Labour Market Institutions and Labour Market Performance, Economics of Transition, Vol. 20, No. 2, pp. 235-269.

Leijonhufvud, A. (1973) Life among the Econ, Western Economic Journal, Vol. 11, No. 3, pp. 327-337.

Leontiev, M. (1994) Gosudarstvo i rynok, Novyi mir, No.12.

Lewis, A. (1954) Economic Development with Unlimited Supplies of Labour, Manchester School of Economic and Social Studies, Vol. 22, No. 2, pp. 139-191.

Mathijs, E. and J. Swinnen (2001) Production Organization and Efficiency during Transition: An Empirical Analysis of East German Agriculture, Review of Economics and Statistics, Vol. 83, No. 1, pp. 100-107.

Monaghan, A. (2012) The Vertikal: Power and Authority in Russia, International Affairs, Vol. 88, No. 1, pp. 1-16.

Nikulin, A. (2002) Kubanskii kolkhoz mezh kholdingom i as'endoi: paradoksy postsovetskoi modernizatsii yuzhnorusskogo sel'skogo soobshchestva, in T. Shanin, A. Nikulin, and V. Danilov (eds.), Refleksivnoe krestíanovededenie: desiatiletie issledovanii sel'skoi Rossii, Moscow: MVShSEN and ROSSPEN.

Ngo, T-W. (2008) Rent-Seeking and Economic Governance in the Structural Nexus of Corruption in China, Crime, Law and Social Change, Vol. 49, No. 1, pp. 27-44.

Nolan, P. (1995) China's Rise, Russia's Fall: Politics, Economics and Planning in the Transition from Stalinism, Basingstoke: Macmillan.

North, D. (1990) Institutions, Institutional Change and Economic Performance, Cambridge: Cambridge University Press. 
North, D. (1993) Institutions and Credible Commitment, Journal of Institutional and Theoretical Economics, Vol. 149, No. 1, pp. 11-23.

Oleinik, A. (2011) Vlast' i rynok: sistema sotsial'no-ekonomicheskogo gospodstva v Rosii “nulevykh” godov, Moscow: ROSSPEN.

Ol'khovskii, A. and S. Tikhonov (2010) Zdravookhranenie Rossii: dvadtsat' let reform, kotorykh ne bylo, St. Petersburg: Nestor-Istoriya.

Ostrom, E. (2010) Beyond Markets and States: Polycentric Governance of Complex Economic Systems, American Economic Review, Vol. 100, No. 3, pp. 641-672.

Polishchuk, L. (1997) Missed Markets: Implications for Economic Behavior and Institutional Change, in J. Nelson, C. Tilly, and L. Walker (eds.), Transforming PostCommunist Political Economies, Washington, DC: National Academy Press.

Pomfret, R. (1997) Growth and Transition: Why Has China's Performance Been So Different? Journal of Comparative Economics, Vol. 25, No. 3, pp. 422-440.

Popov, V. (2012) Russia: Austerity and Deficit Reduction in Historical and Comparative Perspective, Cambridge Journal of Economics, Vol. 36, No. 1, pp. 313334.

Putin, V. (2012) O nashikh ekonomicheskikh zadachakh, Vedomosti, 30 January.

Robinson, J. (1962) Economic Philosophy, London: Watts.

Rodrik, D. (2007) One Economics, Many Recipes: Globalization, Institutions, and Economic Growth, Princeton: Princeton University Press.

Rodrik, D. (2010) Diagnostics before Prescription, Journal of Economic Perspectives, Vol. 24, No. 3, pp. 33-44.

Roland, G. (1994) The Role of Political Constraints in Transition Strategies, Economics of Transition, Vol. 2, No. 1, pp. 27-41.

Roland, G. (2000) Transition and Economics: Politics, Markets, and Firms, Cambridge, MA: MIT Press. 
Rona-Tas, A. (2001) Legacies, Institutions and Markets: Small Entrepreneurship in Hungary, Slovakia and the Czech Republic, in J. Beyer, J. Wielgohs, and H. Wiesenthal (eds.), Successful Transitions: Political Factors of Socio-Economic Progress in Postsocialist Countries, Baden-Baden: Nomos.

Rusinova, D. (2010) Economic Development and Growth in Transition Countries, Amsterdam: Tinbergen Institute.

Sachs, J. (1993) Poland's Jump to the Market Economy, Cambridge, MA: MIT Press.

Saidova, G. and G. Cornia (2005) Linking Macroeconomic Policy to Poverty Reduction in Uzbekistan, Tashkent: Center for Economic Research and UNDP.

Sanfey, P. and U. Teksoz (2007) Does Transition Make You Happy? Economics of Transition, Vol. 15, No. 4, pp. 707-731.

Schmieding, H. (1993) From Plan to Market: On the Nature of the Transformation Crisis, Weltwirtschaftliches Archiv, Vol. 129, No. 2, pp. 216-253.

Shiriaeva, E. (2012) Reformirovanie sistemy dosrochnykh pensii, EKO, No. 2, pp. 8488.

Stone, R. (2002) Lending Credibility: The International Monetary Fund and the PostCommunist Transition, Princeton: Princeton University Press.

Symposium (2002) The IMF and the Ruble Zone, Comparative Economic Studies, Vol. 44, No. 4, pp. 1-84.

van Wijnbergen, S. (1993) Enterprise Reform in Eastern Europe, Economics of Transition, Vol. 1, No. 1, pp. 21-38.

Visser, O. (2008) Crucial Connections: The Persistence of Large Farm Enterprises in Russia, Radboud University Nijmegen, $\mathrm{PhD}$ Thesis.

Wegren, S. (1998) Agriculture and the State in Soviet and Post-Soviet Russia, Pittsburgh: University of Pittsburgh Press.

Williamson, J. (1989) What Washington Means by Policy Reform, in J. Williamson (ed.), Latin American Readjustment: How Much has Happened? Washington, DC: Institute for International Economics. 
Williamson, J. (1992) The Eastern Transition to a Market Economy: A Global Perspective, CEP Occasional Paper, No. 2, London: Centre for Economic Performance.

Williamson, J. (ed.) (1994) The Political Economy of Policy Reform, Washington, DC: Institute for International Economics.

World Bank (1992) Food and Agricultural Policy Reforms in the Former USSR: An Agenda for the Transition, Washington, DC: World Bank.

World Bank (1993) Uzbekistan: An Agenda for Economic Reform, Washington, DC: World Bank.

$\mathrm{Xu}, \mathrm{C}$. (2011) The Fundamental Institutions of China's Reforms and Development, Journal of Economic Literature, Vol. 49, No. 4, pp. 1076-1151.

Yakovlev, A. (2006) The Evolution of Business: State Interaction in Russia: From State Capture to Business Capture? Europe-Asia Studies, Vol. 57, No. 8, 1033-1056.

Yasin, E. (2009) Rossiiskaia privatizatsiia: eshche odin vzglyad, in V. Tambovtseva (ed.), Prava sobstvennosti, privatizatsiya i natsionalizatsiya v Rossii, Moscow: Fond 'Liberal'naia missiya' and Novoe literaturnoe obozrenie.

Yusuf, S. (2009) Development Economics through the Decades: A Critical Look at Thirty Years of the World Development Report, Washington, DC: World Bank. 